\title{
Allergen Determination with Detection of Serum Specific IgE in Dogs with Atopic Dermatitis from Samsun and Vicinity
}

\author{
Öykü BARILI ${ }^{1 *}$, Didem PEKMEZCI'² \\ ${ }^{1}$ University of Ondokuz, Mayıs, Faculty of Veterinary Medicine, Department of Parasitology, Kurupelit, Samsun, Turkey \\ ${ }^{2}$ University of Ondokuz Mayls, Faculty of Veterinary Medicine, Department of Internal Medicine, Kurupelit, Samsun, Turkey
}

\begin{abstract}
It is aimed to detect allergen determination via serum specific immunoglobulin $\mathrm{E}$ (IgE) for the first time in dogs diagnosed as Atopic Dermatitis (AD) from Samsun and vicinity within this present study. Twenty one dogs with different age, breed and gender diagnosed with $\mathrm{AD}$ based up on the Favrot's criteria. Serum samples of the dogs were analyzed by detection of serum specific $\operatorname{IgE}$ for determination of 20 different allergens. The effects of gender, age and the feeding routes for those 20 different allergens separately were analyzed. Based up on the grading of the allergens detected in 21 dogs with $\mathrm{AD}$ from Samsun and vicinity; results reflects that Dermatophagoides farinae was stated as first degree within a very high seropositivity rate $(95 \%)$. Moreover, in varying degree of seropositivitiy rates of other allergens were also detected. Females showed statistically $(\mathrm{p}<0.05)$ higher positivity rate to the $20^{\text {th }}$ allergen, Ctenocephalides spp. more than males. Furthermore, we did not found any significant effects of age and feeding routes on the allergens in the dogs with AD ( $p>0.05)$. Dogs with AD from Samsun and vicinity had very high serum specific $\operatorname{IgE}$ levels against to the house dust and storage mites.
\end{abstract}

Keywords: Allergen, Atopic dermatitis, Dog, Samsun, Specific IgE

\section{Samsun İli ve Çevresindeki Atopik Dermatitisli Köpeklerde Serum Spesifik IgE Tespiti ile Alerjen Tayini}

ÖZ

Bu çalışma ile Samsun ili ve çevresindeki Atopik Dermatitis (AD)'li köpeklerde ilk kez serum spesifik immunoglobin E (IgE) ile alerjen profillerinin belirlenmesi amaçlanmıştır. Değissik 1rk, cinsiyet ve yaşlardaki 21 adet köpeğe Favrot Kriterleri ile AD teşhisi konulmuştur. Köpeklere ait serum örnekleri serolojik olarak 20 farklı alerjene spesifik IgE yönünden incelenmiştir. AD'li köpeklerde 20 farklı alerjenin görülme oranlarına cinsiyet, yaş ve beslenme şekillerinin etkisi araştırılmıştır. Samsun ili ve çevresindeki AD’li köpeklerdeki farklı alerjen profilleri arasında en yüksek \%95 oranında ev tozu akarı Dermatophagoides farinae seropozitifliği saptanmıştır. Bununla birlikte köpeklerde farklı oranlarda diğer alerjenlere yönelik seropozitiflik saptanmıştır. Dişi köpeklerde erkek köpeklere oranla sadece Ctenocephalides spp. seropozitifliğinin yüksek olduğu istatistiksel olarak tespit edilmiştir $(\mathrm{p}<0,05)$. Bununla birlikte AD’li köpeklerde yaş ve beslenme şekillerinin alerjen görülme sıklı̆̆na etkisinin olmadığ1 tespit edilmiştir ( $p>0,05)$. Samsun ili ve çevresindeki AD'li köpeklerde ev tozu ile depo akarlarının serum spesifik IgE değerlerinin çok yüksek oranlarda pozitiflik verdiği saptanmıştır.

Anahtar Kelimeler: Alerjen, Atopik dermatitis, Köpek, Samsun, Spesifik IgE

To cite this article: Barli Ö. Pekmezci D. Allergen Determination with Detection of Serum Specific IgE in Dogs with Atopic Dermatitis from Samsun and Vicinity. Kocatepe Vet J. (2019) 12(4):413-423.

Submission: 01.08.2019 Accepted: 08.10.2019 Published Online: 01.11.2019

ORCID ID; ÖB: 0000-0001-7692-5171, DP: 0000-0003-2072-8165

*Corresponding author e-mail: oykudoyran@hotmail.com 


\section{GİRİŞ}

Yakın zamanda yapılan çalışmalar Köpeklerde Atopik Dermatitis'in (KAD) genellikle diğer kaşıntılı hastalıklarla ilişkili kompleks bir hastalık olduğunu göstermektedir. Bu sebepten dolayı ve KAD doğru teşhis edebilecek bir deri alerji testi eksikliği nedeniyle ve diğer kaşıntılı dermatozlarla karşılaşılabileceğinden dolayı Favrot kriterlerinin tam anlamıyla uygulanmış ve ekarte edilmiş olması gerekmektedir (Favrot ve ark. 2010). Köpek AD'nin klinik tanis1 potansiyel alerjenlerin alerji testleriyle belirlenip, etken eliminasyonu, bu söz konusu olmaz ise desentisizasyon denemelerine geçilmelidir. Geleneksel olarak AD'nin tedavisinde kullanılan immun supresif ajanların potansiyel yan etkileri, maliyetleri ve hasta sahiplerinin tatmin olamamaları bu ilaçların kullanımlarını dolayısı ile de hastaların tedavilerini kısıtlamaktadır. Bundan dolay1 klinik olarak AD teşhisi konulan köpeklerde serum spesifik $\operatorname{IgE}$ ile allerjenlerin belirlenmesi tedavinin en önemli ayağını oluşturmaktadır (Kang ve ark. 2014).

Ayrıca, hastalığın bazı yönleri KAD ile ilgili olmayan diğer deri hastalıklarını taklit edebilmektedir. Köpeklerde ise AD'in patofizyolojisinde rol alan alerjenler arasında ev tozu akarları, bitkiler, artropodlar, epiteller, gidalar ve küf mantarlarinın bulunduğu bildirilmektedir (Halliwell ve ark. 1972, Jeffers ve ark. 1991, Rosser 1993). Baz1 alerjenlerin çevreye özgü olduğu kabul edilmekle beraber, bazılarının iklim ve/veya coğrafi konuma göre de değişebileceği artık günümüzde ortaya konulmuştur. Önemli olan nokta ise bir coğrafi bölgenin veya ülke için geçerli alerjen profilinin farklı coğrafi konumda bulunan ülkeler için önem ihtiva etmeyebileceğidir. $\mathrm{Bu}$ nedenledir ki köpeklerin yaşadıkları coğrafi bölgelere özgü alerjenlerin tespiti son derece önem arz etmektedir.

Veteriner dermatolojide KAD'e klinik olarak neden olan önemli alerjen tayinlerinde teşhis metodları çok hızlı bir şekilde ilerlemektedir. İntradermal Deri Testleri (IDT) ve in vitro antijen-spesifik IgE gibi testler yakın geçmişte köpek hastalarımız için üretilmeye başlamıştır (Nesbitt ve ark. 1984, Sousa ve Norton 1990). Her ne kadar IDT 1990'lı y1llarin başlarında köpek AD'in tedavisinin yönetiminde "Altın Standart" olarak kabul görmüş olsa da testte kullanılan ekstrakların histamin benzeri substratlar ile kontaminasyonun yanlış pozitiflik ve/veya yanlış negatiflik ve alerjenler arası çapraz reaksiyon verme ihtimali testin güvenilirliğini sorgulatır olmuştur (Codner ve Tinker 1995). Yanlış negatif reaksiyonlar ise enjeksiyon tekniğindeki sübjektif hatalara bağlı olarak, alerjen solüsyonun doğru konsantrasyonlarda kullanılmamasına ve köpeğin o dönemdeki immun durumu ile kullanılan ilaçlara bağlı olarak değişmektedir (Nesbitt ve ark. 1984). Bundan dolayı tıpkı beşeri hekimlikte olduğu gibi günümüzde veteriner dermatoloji alanında in vitro olarak çalışılan diyagnostik kitlerin sayıca artması umut vericidir. Son on senede tür spesifik olarak geliştirilen bu kitlerin artık validasyonları da kabul görmektedir.

Alerjenlerin coğrafik koşullarda farklı dağılım göstermesi de o bölgede yaşayan bireyler için önemlidir. Benzer durum veteriner pratik için de geçerlidir. Bundan dolayı bu çalışma ile Samsun ili ve çevresindeki KAD'li köpeklerde ilk kez serum spesifik $\mathrm{IgE}$ ile alerjenlerinin belirlenerek bölgedeki KAD'li köpeklerin tedavisine katkı sağlaması ve diğer sağlıklı köpeklerin belirlenen alerjenlere maruz kalmalarının önüne geçilmesi amaçlanmaktadır.

\section{MATERYAL ve METOT}

\section{Hayvan Materyali}

Hayvan materyalini Nisan 2017 ile Nisan 2018 tarihleri arasında Samsun ve çevresinden kaşıntı şikâyeti ile Ondokuz Mayıs Üniversitesi Veteriner Fakültesi Eğitim Uygulama ve Araştırma Hastanesine tedavi veya kontrol amaciyla getirilen ancak son 1 ay içerisinde mevcut şikâyetine yönelik herhangi bir tedavi yapılmamış, sahipli, çeşitli $1 \mathrm{rk}$, cinsiyet ve yaşlardaki, klinik olarak AD teşhisi konulmuş 21 adet köpek oluşturmuştur. Çalışma yerel hayvan etik kurulunca onaylanmıştır (2016/63). Aynı zamanda hasta sahiplerinden imzalı hasta onam formları alınmıştır. Köpeklerin ırk, yaş ve cinsiyetleri ile getirildikleri bölgelere ait bilgiler kayıt edilmiştir ve sonrasında detaylı klinik muayeneleri gerçekleştirilmiştir. Köpeklerin yapılan fiziksel muayenelerinde dermatolojik muayene formlar1 doldurularak kayıt altına alınmıştır. Tüm fiziksel muayenelerin sonrasinda alerjenlere karş1 serum spesifik IgE düzeylerinin belirlenmesi amaciyla vena cephalica antebrachi'den $5 \mathrm{ml}$ jelli tüplere kan alınarak 3000 rpm'de 10 dakika santrifüj edilmiştir. Serumlar iki farklı ependorf tüpüne aktarılmış ve çalışılana kadar $-20^{\circ} \mathrm{C}$ 'de muhafaza edilmiştir.

\section{Deri Kazıntı Muayenesi}

AD şüphesi taşıyan köpeklerin lezyonlu bölgelerinden derin kazıntı örnekleri lama konularak \%10’luk KOH'te oda 1sısında 15 dakika bekletilmiş ve mikroskop altında Demodex spp./Sarcoptes canis yönünden incelenmiştir. Demodex spp./S. canis pozitif hastalar çalışmaya dâhil edilmemiştir.

\section{Atopik Dermatitis Teşhis Kriterleri}

Köpeklerin detaylı anemnez, fiziksel ve dermatolojik muayenelerinin (mevcut dermatolojik lezyonlar bulundukları bölgeler doğrultusunda şematize edilmiştir) ardından "Atopik Dermatitis" teşhisi Favrot ve ark. (2010)'da belirtilen kriterler dâhilinde konulmuştur. Hasta sahiplerine aynı zamanda hastalar ile ilgili detaylı bilgilere ulaşılması amacıyla sorular yöneltilmiş ve cevapları kayıt altına alınmıştır. 


\section{Serum Spesifik IgE ile Alerjen Tespiti}

Klinik olarak AD teşhisi konulan 21 köpek serumu 20 farklı alerjen içeren Polycheck ${ }^{\circledR}$ Canis (Münster, Germany) alerji tanı kiti ile incelenmiştir. Test kitinde her bir kasette bulunan 20 farklı alerjen Tablo 1'de sunulmuştur. Test prosedürü üretici firmanın direktifleri doğrultusunda çalişılmıştır. Test prosedürüne uygun olarak çalışlan kasetler, üretici firmanın sunduğu yazılımın yüklü olduğu bilgisayardaki tarayıcıda taranmış ve sonuçlar her bir köpek için ayrı ayrı yazdırılmıştır. Her bir alerjen için serum spesifik IgE konsantrasyonlar1 $(\mathrm{kU} / \mathrm{l})$ otomatik olarak yazılım dâhilinde aşağıdaki gibi skorlanmıştır.

Skor $0(<0,5 \mathrm{kU} / \mathrm{l})=$ negatif
Skor $1(0,5-2,0 \mathrm{kU} / \mathrm{l})=$ hafif $/$ zayif
Skor $2(2,0-20 \mathrm{kU} / \mathrm{l})=$ belirgin
Skor 3-4 $(>20 \mathrm{kU} / \mathrm{l})=$ kuvvetli

\section{İstatistiksel Değerlendirme}

AD'li köpeklerde cinsiyet, yaş ve beslenme şekillerinin alerjenlerin görülme oranlarına etkisinin karşılaştırmalarında Ki-kare testi kullanılmışır. $\mathrm{p}<0,05$ değerleri istatistiksel olarak önemli kabul edilmiştir. Tüm analiz ve hesaplamalarda SAS (2013) programı kullanılmıştır.

\section{BULGULAR}

Çalışmaya dâhil olan değişik ırk, cinsiyet ve yaşlardaki 21 adet köpeğe ait veriler Tablo 2'de verilmiştir. Köpeklerin dermatolojik problemlerinin dışında eşlik eden başka bir probleminin olmadığ belirlenmiştir. AD'li köpeklerin dermatolojik lezyonlarının tanımlanması Tablo 3'te gösterilmiștir. AD teşhisi sonrasında serum spesifik IgE tayini ile köpeklerde ortaya konulan alerjen profilleri değişik derecelerde pozitiflik vermiştir (Tablo 4). Alerjenlerin pozitiflik oranları testin sonuçlarının önerilen program dâhilinde taranması sonucunda otomatik olarak hesaplanmıştır. Her bir köpeğe ait alerjen skorlanması ayr1 ayrı rapor edilmiştir. Diğer taraftan alerjenlerin 21 köpekteki görülme oranlarının farklılıkları (Şekil 1) ise istatistikî olarak anlamlı $(p<0,01)$ bulunmuştur. Buna göre 20 alerjen içinden çalışma materyalini oluşturan 21 AD'li köpekte birinci sırada $\% 95$ görülme oranı ile ev tozu akarlarından $D$. farinae yer almaktadır. İkinci sırada yine ev tozu akarlarından olan $D$. pteronyssinus $\% 76$ oraninda yer alırken, 3. sirada $\% 71$ oran gida akarlarından $A$. siro ile 4 . sirada $\% 61$ oranı ile yine gida akarı olan Tyrophagus yer almaktadır. Yirmi alerjen içinde $\% 47$ oranında en sik 5 . olarak görülen Lepidoglyphus, Ryepollen, Grass-Mix alerjenleri yer almıştır. Altıncı sırada \%38 oranında muz familyası bitki polenlerinden Plantain ve kuzukulağı poleni olan Sorrel ile Ctenocephalides spp. yer almaktadır. Gürgen familyası ağaç polenlerinden Birch/Alder/Hazel \%33 görülme oranları ile çalışmada en çok 7 . alerjen grubunu oluşturmuşlardır. Söğüt familyası ağaçların polenleri (Plantane/Willow/Poplar), 1sirgan otu poleni
(Stinging netle) ile albüm otu poleni (Lambs quarter) \%19 görülme oranı ile 8. sırada yer almışlardır. Dokuzuncu sirada yer alan pelin otu poleni olan Mugwort \%14 oranında AD’li köpeklerde görülmüştür. Üç numaralı alerjen olan Malessezia ile 7 numaralı alerjen olan saman nezlesi poleni Ragweed (Ambrosia) \%09,5 görülme oranı ile 10. sırada yer almıştır. Son olarak 11. sırada sadece bir köpekte görülen $\% 4,8$ oranı ile Aspergillus/Penicillium ve yapışkan otu poleni olan Parietaria (Wall pellitory) yer almaktadır. Altı numaralı alerjen olan klado küfü Alternaria/Cladosporium ise çalışma köpeklerinin hiçbirinde pozitiflik vermemiştir. AD teşhisi konulmuş 21 vakanın 12'sini dişi, 9'unu da erkek köpek oluşturmuştur (Tablo 4). Köpeklerdeki cinsiyete bağlı alerjen görülme olasıllkları her farklı alerjen için ayrı ayrı araştırılmış olup, sadece 20. alerjen olan Ctenocephalides spp.'nin dişi köpeklerde görülme oranının erkek köpeklere oranla istatistiki olarak $(p<0,05)$ daha fazla olduğu tespit edilmiştir. Diğer alerjenlerin cinsiyet bazında görülme oranlarında istatistikî olarak anlamlı olmadığ tespit edilmiştir ( $\mathrm{p}>0,05)$.

Çalışmamız köpeklerinden en küçüğü 1,5 yaş iken en büyügü 17 yaşında olup ortalama 5,2 yaştır. Ancak yaş farklılıklarına göre alerjen görülme siklikları bakımından yapılan karşılaştırmada AD teşhisinde kullandığımız Favrot kriterlerince 2 yaş grubu olan 3 yaş altı ve 3 yaş üstü grupları değerlendirmeye alınmıştır. Bu bağlamda 3 yaş altı grubunu 9 adet köpek oluştururken, 3 yaş üstü grubu 12 adet köpek oluşturmuştur (Tablo 2). Üç yaş altı ve 3 yaş üstü gruplarının 20 farklı alerjeni gösterme olasılıkları değerlendirilmiş ancak gruplar arasında istatiksel bir farklılık bulunamamıştır $(\mathrm{p}>0,05)$.

Hasta sahiplerinden alınan bilgiler doğrultusunda AD teşhisi konulmuş 21 köpeğin 9'u sadece kuru mama (K) ile beslenirken, 11 köpeğin kuru mama ve ev yemekleri (KE) ile beslendiği öğrenilmiştir. Sadece 1 köpeğin ise yalnızca ev yemekleri (E) ile beslenildiği tespit edilmiştir. Sadece ev yemekleri ile beslenen 1 köpek veri setine dâhil edilmemiştir. $\mathrm{K}$ ve $\mathrm{KE}$ grupları arasında beslenme şekillerine bağlı alerjen görülme olasılıkları her farklı alerjen için ayrı ayrı araştırılmış ve gruplar arasında istatiksel bir farkllilk tespit edilememiştir $(p>0,05)$.

Bununla beraber 20. alerjen olan Ctenocephalides spp. için K grubunun KE'ye göre sınırda önemlilik $(\mathrm{p}>0.08)$ gösterdiğini ancak bu durumun istatiksel olarak bir öneminin olmadığı sonucuna varılmıştır. 
Tablo 1. Polycheck ${ }^{\circledR}$ Canis (Münster, Germany) Alerji Tan1 Kitlerine ait 20 adet farklı alerjen

Table 1. Twenty different allergens belong to the Polycheck ${ }^{\circledR}$ Canis (Münster, Germany) Allergy Diagnostic Kit

\begin{tabular}{|c|c|c|}
\hline Alerjen No & Alerjen Ad1 & Alerjenlerin Geleneksel İsimleri \\
\hline 1 & D.farinae & Ev Akar1 Tip-1 \\
\hline 2 & D.pteronyssinus & Ev Akar1 Tip-2 \\
\hline 3 & Malassezia & Malessezia \\
\hline 4 & Lepidoghphus & G1da Paraziti \\
\hline 5 & Aspergillus/ Penicillium & Aspergillus/ Penicillium \\
\hline 6 & Alternarial Cladosporium & Klado Küfü \\
\hline 7 & Ragweed (Ambrosia) & Saman Nezlesi Poleni \\
\hline 8 & Birch/ Alder/ Hazel & Gürgen Familyası Ağaçların Polenleri \\
\hline 9 & Plantane/ Willow/ Poplar & Söğüt Familyası Ağaçların Polenleri \\
\hline 10 & Parietaria (Wall pellitory) & Yapışkan Otu Poleni \\
\hline 11 & Ryepollen & Çavdar Poleni \\
\hline 12 & Grass-Mix & Çimen/Ot Tiplerinin Polenleri* \\
\hline 13 & Stingingnettle & Isırgan Otu Polenleri \\
\hline 14 & Lambsquarter & Albüm Otu Poleni \\
\hline 15 & Plantain & Muz Familyası Bitki Polenleri \\
\hline 16 & Mugwort & Pelin Otu Poleni \\
\hline 17 & Sorrel & Kuzukulağ1 Poleni \\
\hline 18 & Acarus siro & Bitki Akarı \\
\hline 19 & Tyrophagus & Un Akar1 \\
\hline 20 & Flea (Ctenoceph.) & Pire \\
\hline
\end{tabular}

Tablo 2. AD teşhisi konulmuş 21 adet köpeğin 1 rk, cinsiyet ve yaşlarına ait veriler

Table 2. Data of breed, sex and ages belong to the 21 dogs diagnosed with AD

\begin{tabular}{|c|c|c|c|}
\hline Vaka Numaras1 & Irk & Cinsiyet & Yaş \\
\hline 1 & G & Dişi & 10 \\
\hline 2 & G & Dişi & 11 \\
\hline 3 & $\mathrm{~T}$ & Erkek & 1,5 \\
\hline 4 & $\mathrm{H}$ & Erkek & 9 \\
\hline 5 & $\mathrm{~T}$ & Erkek & 4 \\
\hline 6 & CC & Erkek & 1,5 \\
\hline 7 & $\mathrm{D}$ & Dişi & 3,5 \\
\hline 8 & P & Dişi & 4 \\
\hline 9 & PB & Dişi & 5 \\
\hline 10 & M & Dişi & 3 \\
\hline 11 & $\mathrm{D}$ & Erkek & 2,5 \\
\hline 12 & M & Dişi & 4 \\
\hline 13 & P & Erkek & 17 \\
\hline 14 & B & Dişi & 8 \\
\hline 15 & $\mathrm{BM}$ & Dişi & 2 \\
\hline 16 & KCS & Erkek & 9 \\
\hline 17 & G & Dişi & 8 \\
\hline 18 & JR & Erkek & 2 \\
\hline 19 & $\mathrm{~T}$ & Dişi & 2 \\
\hline 20 & K & Dişi & 2 \\
\hline 21 & $\mathrm{~T}$ & Erkek & 1 \\
\hline
\end{tabular}

G: Golden Retriever; T: Terrier; H: Husky; C: Chow Chow; D: Doberman; P: Pug; PT: Pitt Bull; M: Melez; PK: Pekinese; B: Boxer; BM: Belçika Malonese; KCS: King Charles Spaniel; JR: Jack Russell; K: Kangal 
Tablo 3. AD teşhisi konulmuş 21 adet köpeğe ait "Dermatolojik Lezyonlar"

Table 3. "Dermatological Lesions" belong to the 21 dogs diagnosed with AD

\begin{tabular}{|c|c|c|c|c|c|c|c|c|c|c|c|c|c|c|c|c|c|c|c|c|c|}
\hline \multirow[t]{2}{*}{ Dermatolojik Lezyonlar } & \multicolumn{21}{|c|}{ Vaka Numarası } \\
\hline & 1 & 2 & 3 & 4 & 5 & 6 & 7 & 8 & 9 & 10 & 11 & 12 & 13 & 14 & 15 & 16 & 17 & 18 & 19 & 20 & 21 \\
\hline Lezyonsuz kaşıntı & $\checkmark$ & $\checkmark$ & & & & & & $\sqrt{ }$ & & & $\checkmark$ & $\checkmark$ & & $\checkmark$ & & & $\checkmark$ & $\checkmark$ & $\checkmark$ & & $\checkmark$ \\
\hline \multicolumn{22}{|l|}{ Primer Deri Lezyonları } \\
\hline Eritem & $\checkmark$ & & & & & & & & $\checkmark$ & & & & & & $\checkmark$ & & & & & $\checkmark$ & \\
\hline Papül & $\checkmark$ & $\checkmark$ & & & & & & & $\checkmark$ & & & & & & & & & & & & \\
\hline Püstül & & & & & & & & & & & & & & & & & & & & $\checkmark$ & \\
\hline \multicolumn{22}{|l|}{ Sekonder deri lezyonları } \\
\hline Epidermal kollaret & & & & & & & & & & & & & & & & & & & & & \\
\hline Kabuklanma & & $\checkmark$ & $\checkmark$ & & $\checkmark$ & $\checkmark$ & & & $\checkmark$ & $\checkmark$ & & & & & $\checkmark$ & & & & & $\checkmark$ & \\
\hline Tükürükle boyanma & & & & $\checkmark$ & & $\checkmark$ & & & & $\checkmark$ & & & $\checkmark$ & $\checkmark$ & & & & $\checkmark$ & & & \\
\hline Soyulmalar & & & & & & & & & & & & & & & $\checkmark$ & & & & & $\checkmark$ & \\
\hline Alopesi & & & $\checkmark$ & & & & $\checkmark$ & & $\checkmark$ & & & & $\checkmark$ & & $\checkmark$ & $\checkmark$ & & & & & \\
\hline Likenifikasyon & & & & & & & & & & & $\checkmark$ & & & $\checkmark$ & $\checkmark$ & $\checkmark$ & & & & & \\
\hline Hiper-pigmentasyon & & $\checkmark$ & & $\checkmark$ & $\checkmark$ & & & & & $\checkmark$ & $\checkmark$ & & $\checkmark$ & $\checkmark$ & $\checkmark$ & $\checkmark$ & & & & & \\
\hline
\end{tabular}

Tablo 4. AD teşhisi konulmuş 21 adet köpeğe ait "Alerjen Profilleri”"

Table 4. "Allergen Profiles" belong to the 21dogs diagnosed with AD

\section{$\begin{array}{ll}\text { ALERJEN } & \text { VAKA NUMARASI }\end{array}$}

\begin{tabular}{lllllllllllllllllllll}
\hline 1 & 2 & 3 & 4 & 5 & 6 & 7 & 8 & 9 & 10 & 11 & 12 & 13 & 14 & 15 & 16 & 17 & 18 & 19 & 20 & 21
\end{tabular}

\section{CİNSİYET}

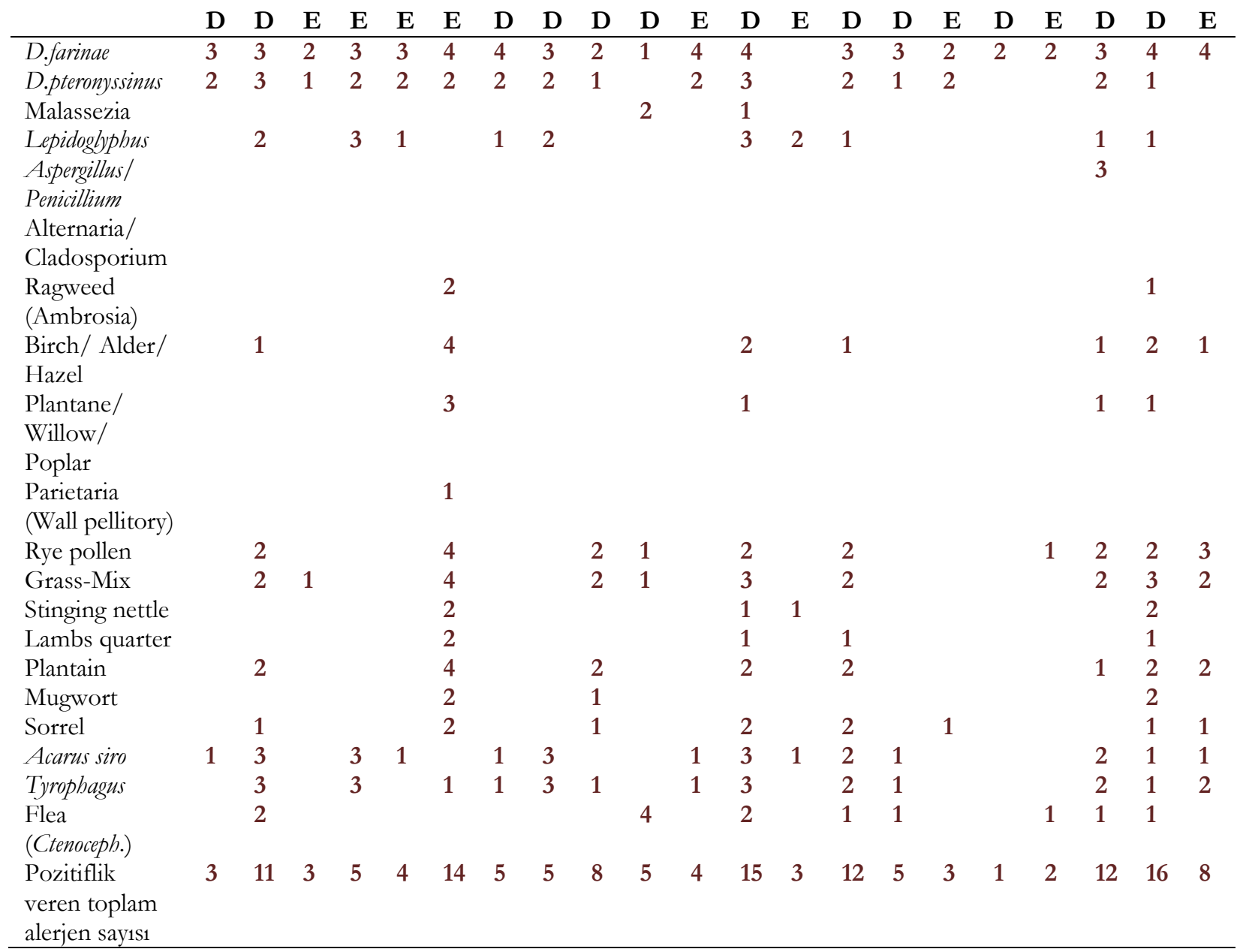

D: Dişi; E: Erkek,Skor 1 (0,5-2,0)=hafif/zayıf, Skor 2 (2,0-20)=belirgin, Skor 3,4 (>20)=kuvvetli 


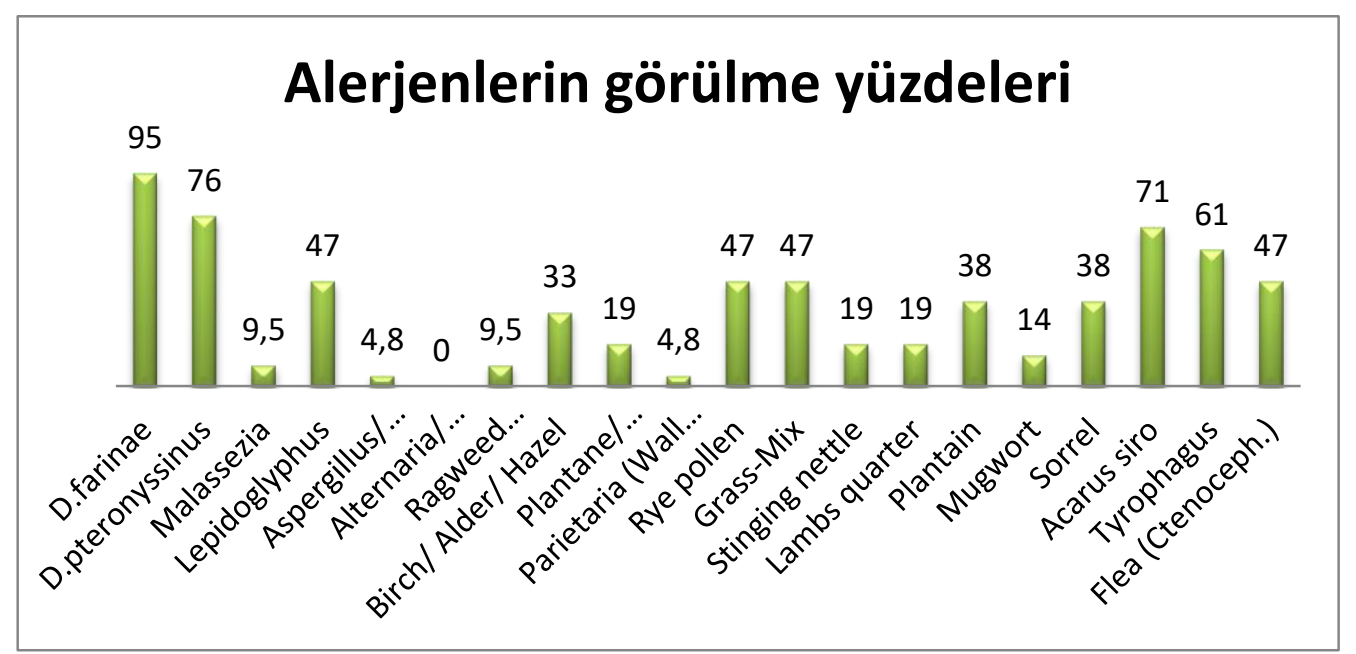

Şekil 1. AD teşhisi konulmuş 21 adet köpeğe ait 20 farklı alerjenlerin pozitiflik yüzde (\%) oranları. Farklıllklar istatistiki olarak anlamlı bulunmuştur, $\mathrm{p}<0,01$.

Figure1. Seropositivity rates of the 20 different allergens belong to the 21 dogs diagnosed with AD. Differences were found as statistically significant, $\mathrm{p}<0.01$.

\section{TARTIŞMA}

Köpeklerde AD'e neden olan alerjilerin tespiti, yatkın olan köpek 1rkları ve bunların tedavileri gibi litearatürde sayısız çalıșma mevcuttur. Ancak bu çalışmaların hiç biri sadece bir ırka özgü alerjen profilini ortaya koyma yönünde istikrarlı olamamıştır. Bu durumun bir nedenini ise AD’li köpeklerde yaygin alerjen profilini ortaya koyma yönündeki çalışmalarda da köpek ırklarının istatiksel hesaplamaya yetecek kadar eșit sayıda dağılım gösterememesi yer almaktadır. $\mathrm{Bu}$ durum çalışmamız materyalini oluşturan köpek ırklarımız için de geçerlidir. Öyle ki 14 farkl 1 rk grubundan hiç birinde istatiksel analize uygun denek sayısına ulaşılamamıştır. Ancak 20 numaralı Kangal 1rk1 köpeğimizin 20 farklı alerjen profili değerlendirilmesinden 16 farklı alerjene aynı anda pozitiflik vererek çalışmayı olușturan 21 köpekten en fazla alerjene reaksiyon veren 1rk olduğunu söyleyebiliriz. Bununla beraber, ülkemizdeki AD'li köpeklerde IDT ile alerjen profillerini ortaya koyan çalışma kapsamında da Kangal ırkının yer aldığını görmekteyiz (Temizel ve Aytug 2011). Kim ve ark. (2011) yllinda KAD’li köpeklerdeki alerjen profilini IDT ile ortaya koydukları çalışmalarında 58 köpeğin çoğunluğunu Maltase ve Shih-tzu ırklarının oluşturduğunu ancak, bu sonucun Kore'deki hayvan sahiplerinin evde bakılması kolay olan bu irkların tercih edilmelerine bağlı olarak ortaya çıkmış olabileceğini belirtmişlerdir.

Zur ve ark. (2002) yllinda retrospektif olarak gerçekleştirdikleri çalışmada Kaliforniya Üniversitesi Veteriner Fakültesi Eğitim ve Araştırma Hastanesi'ne 1992-1998 y1llar1 arasinda bak1lan 266 adet AD'li köpek arasinda Labrador Retriever, Golden Retriever, West Highland White Terrier, English Springer Spaniel, Chinese Shar-Peis, Bull Terrier, Bichon Frisés ve Tibetan Terrier ırkları diğerlerine göre istatiksel olarak yüksek oranda AD'e sahip olduğunu tespit etmişlerdir. Aynı zamanda Labrador Retriever, Golden Retriever, West Highland White Terrier 1rk1 köpekler Ihrke ve ark. (1985)'nın çalışmalarında da en sık AD teşhisi konulan köpek ırklarını oluşturmuşlardır.

AD’li köpeklerde 1rk farklılıklarının belirlenmesindeki kısitlamalar cinsiyet farkliliklarında da ortaya çıkmaktır. Bu konuda cinsiyet farklılıklarının AD şekillendirme potansiyellerine özgü çalışmaların sayısı veteriner pratikte oldukça azdır.

Çevresel ve diyet ile ilgili farkllikların KAD'i oluşturma ihtimallerini inceleyen çalışmalar cinsiyet, doğum sezonu, çevre (ev, coğrafya ve diğer hayvan temasları), aşılama ve anti paraziter tedavi uygulamalarının KAD'i oluşturma ihtimallerini açıklayan çalışmaların önüne geçilmektedir (Nødtvetd ve ark. 2007). İsviçre'deki Boxer, Bullterrier ve West Highland köpek ırklarında AD görülmesine yönelik risk faktörlerinin incelendiği vaka kontrollü meta analiz çalışmasının ana bulgusu olarak araştırıcilar ev yemekleri ile beslenen gebe köpeklerin yavrularında AD'in ortaya çıkma olasıllğının diğerlerine nazaran daha düşük olduğunu ortaya koymuşlardır. $\mathrm{Bu}$ bağlamda, KAD'in görülmesine neden olabileceği cinsiyet faktörünün araștırıldığı çalıșmalarda tutarsızlıklar bulunmaktadır ve günümüzde de halen bu sorun netliğe kavuşmuş değildir. Örneğin, bir çalışmada erkek köpeklerde KAD görülme ihtimalinin yüksek olduğu bildirilirken (Nesbitt 1978), farklı çalışmalarda dişi köpeklerde bu yatkınlığın daha fazla olduğu belirtilmiştir (Halliwell ve ark. 1972, Scott 1981, Nesbitt ve ark. 1984). Diğer taraftan cinsiyet farklılıklarının KAD gelișiminde önemsiz olduğunu belirten çalışmalar da literatürde mevcuttur (Willemse ve van den Brom 1983, Carlotti ve Costargent 1992, Saridomichelakis ve ark. 1999). 
Bu çalışmada ise 21 KAD'li köpeğin 12'sinin diși, 9'nun da erkek olduğu tespit edilmiştir. Köpeklerdeki cinsiyete bağlı alerjen görülme olasılıkları her farklı alerjen için ayrı ayrı araştırdığımızda sadece 20. alerjen olan Ctenocephalides spp.'nin dişi köpeklerde görülme oranının erkek köpeklere oranla daha fazla olduğu $(p<0,05)$ tespit edilirken diğer alerjenlerin cinsiyet bazında görülme oranlarında istatistiki olarak anlamlı olmadığ tespit edilmiştir. $\mathrm{Bu}$ bakımdan sonuçlarımızın bazı çalışmalar (Halliwell ve ark. 1972, Scott 1981, Nesbitt ve ark. 1984) ile örtüssmekle beraber bu çalışmaların hepsinin IDT ile yapıldığının belirtilmesi gerekmektedir. Çoğu çalışmalarda alerjen profillerinin cinsiyete bağlı olarak değişmediğini, her iki cinsiyette de alerjenlerin görülme oranlarının benzerlikler taşıdıkları belirtilmiştir. Öte yandan Zur ve ark.(2002) dişi köpeklerin çim ve insekt alerjenlere pozitiflik verme oranlarının erkeklere oranla daha fazla olduğunu bildirmişlerdir. $\mathrm{Bu}$ sonuç, çalışmamızdaki dişi köpeklerin sadece Ctenocephalides spp.'nin görülme oranlarının erkeklere göre istatistiksel olarak daha fazla olduğu sonucu ile de örtüşmektedir.

Öte yandan cinsiyet farklılıklarının önemini araştıran çalışmalarda köpeklerin kısırlaştırılma veya kastrasyon durumlarının da değerlendirilmeye alınması gerekliliği vurgulanmaktadır.

Genel olarak KAD'in başlangıç yaş aralığı tipik olarak 6 ay ile 3 yaş arasında değişmektedir. Klinik bulguların ise 6 aylıktan küçük ve 7 yaşından büyük köpeklerde görülmediği düşünülmektedir (Nesbitt ve ark. 1984, Scott ve ark. 1995, Saridomichelakis ve ark. 1999, Griffin ve DeBoer 2001). Aslında genç köpeklerde $\mathrm{AD}$ görülme olas1likları diğer dermatolojik problemlerin görülme olasılıklarından daha yüksektir (Prelaudve ark. 1998). Yine Zur ve ark. (2002) KAD’li köpeklerin yaş ortalamalarının 1,6 olduğunu, fakat yaşın alerji görülme oranlarına bir etkisinin olmadığını savunmuşlardır.

Çalışmamızdaki köpeklerin en küçüğü 1,5 en büyüğü 17 yaşında olup yaş ortalaması 5,2 olarak tespit edilmiştir. Ancak yaş farklılıklarına göre alerjen görülme sıklıkları bakımından yapılan karşılaştırmada $\mathrm{AD}$ teşhisinde kullandığımız Favrot kriterlerince 2 yaş grubu olan 3 yaş altı ile 3 ve üstü yaş grupları değerlendirmeye alınmıştır. Bu bağlamda, 3 yaş altı grubunu 9 adet köpek oluştururken, 3 yaş ve üstü grubu (3 yaş dâhil olmak üzere) 12 adet köpek oluşturmuştur. Üç yaş altı ve 3 yaş ve üstü gruplarının 20 farklı alerjeni gösterme olasıllkları değerlendirilmiş ancak gruplar arasinda istatiksel bir farklilik bulunamamıştır. Bu bağlamda mevcut sonuçlarımız diğer çalışmalar ile örtüşmektedir (Willemse ve ark. 1984, Scott ve ark. 1995, Zur ve ark. 2002, Kang ve ark. 2014). Kim ve ark. (2011) ise 58 AD'li köpekte alerjen profillerini belirledikleri çalışmada köpeklerin yaş ortalamaların 4,8 olduğunu ve $\% 70$ oranında klinik bulgu gösterme eğiliminde olanların 3 yaş ve altında olduklarını belirtmişlerdir.

Ayrıca, sadece ev yemekleri ile beslenen 1 köpek dışındaki, kuru mama ve kuru mama/ev gidası grubunu oluşturan köpeklerde beslenme şekillerine bağlı alerjen görülme olasılıkları her farklı alerjen için ayrı ayrı araştırılmış olup gruplar arasında istatiksel bir farklılık bulunamamıştır. Bununla beraber 20. alerjen olan Ctenocephalides spp. için kuru mama grubunun kuru mama/ev gidası grubuna göre sınırda önemlilik $(p>0.08)$ gösterdiğini ancak bu durumun istatiksel olarak bir öneminin olmadığı sonucuna varılmıştır. Bu bağlamda önceki literatürlerde beslenme şekilleri ile pire alerjenine pozitiflik gösterme ihtimalleri dikkate alınmamış olup bu durum ilk kez mevcut çalışmamızla ortaya konulmuştur.

Çalışmamızdaki serum spesifik IgE test sonuçları ev tozu akarlarının $D$. farinae ve $D$. pteronyssinus'un siras1 ile $\% 95,2$ ve $\% 76,1$ ile diğer alerjenlere göre en çok görülen alerjenler olduğunu göstermiştir. $\mathrm{Ev}$ tozu akarlarının benzer şekilde insanlar için de en çok karşılaşılan alerjenler olduğu bilinmekle (De Weck 1995, Hill ve DeBoer 2001) beraber Samsun ili sınırları içerisindeki ev ve iş yerlerinin toz faunaları içinde ev tozu akalarından $D$. farinae ve $D$. pteronyssinus'un en çok karşılaşılan alerjenler olduğu tespit edilmiştir (Açıcı ve ark. 2009). Masuda ve ark. (2000) 42 AD teşhisi konulmuş köpekte yapmış oldukları çalışmada araştırıcılar hem IDT hem de in vitro olarak serum spesifik $\operatorname{IgE}$ ile yaygin alerjenleri tespit etmişlerdir. Bu çalışmalarında araştırıcılar en yaygin alerjenin \%54,4 (23/54) oraninda ev tozu akarlarının olduğunu bulmuşlardır (Masuda ve ark. 2000). Sunulan çalışmamızdaki ev tozu akarlarına yönelik alerji oranlarımız $D$. farinae'nın $D$. pteronyssinus için sıras1 ile \%95,2 ve \%76,1 olarak Japonya'da yapılmış olan çalışmaya göre (Masuda ve ark. 2000) oldukça yüksek bulunmuştur. Yine Masuda ve ark. (2000) yapmış oldukları çalışmada IDT ile $D$. farinae'nın D. pteronyssinus'a göre daha yüksek oranda pozitiflik verdiğini saptamışlardır. Benzer sonuçlar çalışmamız için de geçerli olmuştur. Zira sunulan çalışmada D. farinae'nın 21 AD'li köpeğin 20'sinde pozitiflik verdiği $(\% 95,2)$ görülmüştür. Öte yandan yine çalışmamızda $D$. pteronyssinus'a karşı pozitiflik oranı \% 76,1 olarak bulunmuştur. Bu sonuçlar Birleşik Krallık'ta yapılan ev tozu akarlarına yönelik alerjisi olan köpeklerde en fazla görülen alerjenin $D$. farinae olduğu sonucu (Sture ve ark. 1995) ve yine Japonya'daki AD'li köpeklerdeki yaygin alerjenlerin tespitini amaçlayan ve en çok pozitiflik veren alerjenin $D$. farinae olduğu sonucu ile de örtüşmektedir (Masuda ve ark. 2000).

Benzer şekilde Amerika Birleşik Devletleri, Kuzey Kaliforniya'da 266 AD'li köpeğin alerjen profillerinin belirlenmesine yönelik çalışmada Zur ve ark. (2002) ev tozu akarlarının \%71 oranında en fazla görülen alerjen olduğunu belirlemişlerdir. Araştırmacıların bu 
sonuçları çalışmamız sonuçları ile de örtüşmektedir. Diğer taraftan Kim ve ark. (2011) Kore'de 58 AD teşhisi konulmuş Maltase 1rkı köpeklerde IDT ile alerjen tayinlerinde ev tozu akarlarına yönelik sadece \%49,1 oranında pozitiflik bulmuşlardır. Bu oran, bu çalışmada elde edilen bulgulara göre değerlendirildiğinde daha düşük bulunmuştur. Kang ve ark. (2014)'nın Kore'de 101 AD köpeğin 92 alerjene yönelik in vitro serum spesifik $\operatorname{IgE}$ tayini ile yapılan çalışmalarında ise ev tozu akarlarının pozitiflik oranın çalışmadaki en yüksek pozitiflik oranına $(\% 61,4)$ sahip olduğunu bildirmişlerdir. Aynı araştırmacıların ev tozu akarlarına yönelik AD'li köpeklerde farklı sonuçlar elde etmeleri ise test yöntemlerinin farklı olması ile açıklana bilinir. Ülkemizdeki AD'li köpeklerde alerjen tayini belirlenmesine yönelik yapılan çalışmalar oldukça kisitlidir. Temizel ve Aytug (2011) yilında 50 adet AD'li köpekte 16 farklı alerjenin tayinini IDT ile gerçekleştirmişler ve ev tozu akarlarının \%66 oranında pozitiflik verdiği, bunlardan da en çok pozitiflik veren alerjenin $D$. farinae olduğu sonucunu rapor etmişlerdir. Araştırmacıların çalışması ile sunulan sonuçlarımız örtüşmektedir.

Köpek alerji testleri ile mevcut literatürde yaygın olmayan ancak çalışmamız kit içeriğinde bulunan ve sonuçlar1 itibar1 ile en yayg1n 3. sirada $\% 71$ oran1 ile depo akarlarindan $A$. siro ile 4. sirada $\% 61$ oran1 ile diğer bir depo akarı olan T. putrescantiae $\% 47$ oranında en s1k 5. olarak görülen ise Lepidoglyphus yer almaktadır. Veteriner pratikte KAD'li hastaların alerjen profil değerlendirilmesi yapılan çalışmalarda bahsi geçen depo akarları çoğu çalışmada toplu olarak değerlendirilmiş ve ayrı türlerde spesifik olarak çalışılmak yerine topluca çalışılmış olması sonuçlarımızın kıyaslanmasına olanak tanımamıştır. Bununla beraber, $A$. siro ve T. putrescantiae'nin karışım halinde tek alerjen olarak ELISA ile değerlendirilen çalışmalarda araştırıcılar Hammerling ve De Weck (1998) (Immunodot); Hammerling ve De Weck (1998) (ELISA); Zunic (1998) (Immunodot) siras1 ile AD’li köpeklerde bu alerjenlerin $\% 80, \% 37$ ve $\% 38$ oranında pozitiflik verdiğini bildirmişlerdir.

Zur ve ark. (2002)'nın yapmış oldukları çalışmada 266 AD'li köpekten 76'sının hem ev tozu akarlarına hem de pireye karşı reaksiyon verdiklerini bildirmişlerdir. Çalışmamızda ise depo akarlarından $A$. siro ve $T$. putrescantiae'ya karş1 pozitiflik veren köpeklerin aynı zamanda $D$. farinae ile $D$. pteronyssinus'a pozitiflik verme oranları oldukça yüksek bulunmuştur. Örneğin bir bitki akarı olan $A$. siro'ya karşı pozitif olan köpeklerin \%92'sinin D. farinae'ya, diğer taraftan ayn köpeklerin D. pteronyssinus'a \%100 pozitiflik verdiği dikkat çekmektedir.

Aynı zamanda çalışmamızda bir un akarı olan $T$. putrescantiae'ya pozitiflik veren 13 köpeğin \%100'ünün D. farinae'aya, $\% 92$ oraninda da D. pteronyssinus'a pozitiflik verdiğini görmekteyiz. Bununla beraber Lepidoglyphus'a pozitiflik veren 10 köpeğin tamamının D. farinae'aya ve D. pteronyssinus'a \%90 oraninda pozitiflik verdiğini görmekteyiz. Bu sonuçlar gida akarlarına pozitiflik veren tüm köpeklerin ev tozu akarlarına da yüksek oranda pozitiflik verdiğini göstermektedir.

Özellikle depo akarlarının köpek kuru mama yapımı esnasında gidaya geçerek köpeklere alerjik reaksiyon veren protein kaynaklarını oluşturabileceğini düşünmekteyiz. Öyle ki çalışmamızı oluşturan 21 köpekten 20'sinin kuru mama tüketim öyküsü bulunmaktadır. Aynı zamanda çalışma sonunda hasta sahiplerine uyguladı̆̆ımız anket sonucunda büyük çoğunluğunun aynı kuru mama markasını kullandıkları tespit edilmiştir. Bu sonuç bahsi geçen akarların kuru mamalardaki mevcut yüklerinin incelenmesi gerekliliğini ortaya çıkarmıştır.

Alerjen profili değerlendirmesinde küf grubunda bulunan Malassezia, Aspergillus/Penicillium ve Alternaria/Cladosporium lar diğer çalışmalarda oldukça yüksek oranda pozitiflik vermişlerdir. Örneğin Zur ve ark. (2002) değişik küf türlerinin 160 köpekte \%60 oranında pozitiflik verdiğini bu grup alerjenin ise totalde ev tozu akarlarından sonra en çok pozitiflik veren ikinci alerjen grubu olduğunu belirtmişlerdir. Diğer taraftan Kim ve ark. (2011) küf alerjenlerini $\% 67,3$ oranında en yüksek pozitiflik veren grup olduğunu belirtmişlerdir. Masuda ve ark. (2000) ise küf mantarlarının çalışmalarında \%16,7'lik bir oranla AD’li köpeklerdeki en düşük pozitiflik veren grup olduğunu tespit etmişlerdir. Çalışmamız küf grubunu oluşturan alerjenlerden Malessezia \% \%,5 görülme oranı ile 10. sirada yer alırken, $\% 4,8$ oranı ile 11 . s1rada Aspergillus/Penicillium sadece bir köpekte görülmüştür. Altı numaralı alerjen olan klado küfü Alternaria/Cladosporium ise hiçbir köpekte pozitiflik vermemiştir. Elde ettiğimiz bu sonuçlar Masuda ve ark. (2000) ve Temizel ve Aytug (2011) ile örtüşmektedir. Öte yandan Kang ve ark. (2014) yapmış oldukları çalışmada ise küf mantarları grubunun KAD’lı köpeklerde \%39,6 oranında, Malessezia'y1 ise \%21,9 oranında pozitif olarak bulmuşlardır. Araştırıcıların bu sonuçları da mevcut çalışmamızdan oldukça yüksektir. Küf mantarlarının AD’li köpeklerde pozitiflik oranlarının araştırıldığ1 çalışmalardaki oranların farklılıkları köpeklerin yaşam alanlarının coğrafi, iklim ve nem oranları ile testlerin yapılış metotlarının farklılıklarından da şekillenebilmektedir. Zira serum spesifik IgE'nin IDT'ye oranla küf mantarlarının tespitinde yetersiz kaldığ1 ve bu teknik ile ölçülen sonuçların güvenirliliğinin sorgulanabileceği belirtilmektedir. Küf mantarlarına karşı klinik belirtilerin şekillenme oranı ve bu grup alerjenlere pozitiflik verme oranlarının yüksek rutubet ve nem oranın olduğu kiş aylarında daha yüksek olduğu bildirilmekle beraber çalışmamız köpeklerinin çoğunluğun numune toplama 
zamanlarının kış ayı içerisinde olduğu ancak toplamda yine çalışma köpeklerimizin bu grup alerjene pozitiflik verme oranlarının oldukça düşük olduğu tespit edilmiștir. Bu durum iklim açısından oldukça nemli olan Samsun ilinde yaşayan köpekler için beklenmeyen bir sonuç olarak karşımıza çıkmaktadır. Ancak, gerek serolojik gerekse IDT olarak gerçekleştirilen ve AD’li köpeklerde küf mantarlarının değerlendirildiği çalışmalarda çoğunlukla bu grubun içinde yer alan ekmek küfü olan Rbizopus'usun ayrı ya da karışım olarak çalışıldığını belirtmek gerekir. Beraberinde Rhiropus'usun bu çalışmalarda oldukça yüksek oranda pozitiflik verdiği de bildirilmektedir (Masuda ve ark. 2000, Zur ve ark. 2002, Kim ve ark. 2011, Kang ve ark. 2014).

Çevresel alerjenlerin başında hava kaynaklı alerjenler gelmektedir. Özellikle dış çevre ortamında yer alan çevresel alerjenler ana başlıklar halinde çim, ağaç ve ot polenleri olarak siniflandırilabilirler. Cocksfoot, Meadow Fescue, Rye çim, Timothy çim, Kentucky Blue çim, Velvet çim poleni olmak üzere 6 farklı çim polenini içermektedir. Ağaç polenlerini Plantane/Willow/Poplar ve Birch/Alder/Hazel oluşturmaktadır. Ot polenleri ise çalışmamız kit paneli içeriğinde yer alan Parietaria (Wall pellitory), Ryepollen, Ragweed (Ambrosia), Stinging netle, Lamb'squarter, English Plantain, Mugwort, SorrePdir. Avustralya'da 1000 'den fazla atopik köpekte herhangi bir polene (çim, ağaç ya da ot) karş1 \%10 ila \%25 oranında hassasiyet IDT ile tespit edilmiştir (Mueller ve ark. 2000). Fransa'nın batısında yapılmış bir çalışmada ise AD'li köpeklerde polen hassasiyetinin cinsiyet, ırk, mevsim ve yaşa bağlı olmadığı tespit edilmiştir (Roussel ve ark. 2013).

Bireylerdeki polen hassasiyetini bölgelerindeki farlılıklar olmak kaydı ile bitki türleri belirlemektedir. Masuda ve ark. (2000) 48 köpekte Japonya'da yapmış oldukları çalısmada bu ülkeye endemik olan Japon çedar polenine (Cryptomeria japonica) karşı köpeklerdeki hassasiyetin ev tozu akarlarından sonra $\% 50$ oranı ile en yüksek oranda görülen 2. alerjen olduğunu ortaya koymuşlardır.

Önemli bir bulgu da köpeklerdeki çim polenine karş1 hassasiyetin tıpk1 insanlardaki gibi artış göstermiş olmasıdır. Öyle ki 1990 ila 2000 yıllarında \%14,4 olan bu oran 2007 ila 2010 y1llar1 arasinda \%27,7'ye yükselmiştir.

Çalışmamızda 20 alerjen içinde $\% 47$ oranında en sık olarak görülen, 5. Alerjen Grass-Mix'tir. Sonuçlarımız (\%47) sırası ile AD’li köpeklerde \%15 (Sture ve ark. 1995), \%31,4 (Masuda ve ark. 2000), \%35,3 (Zur ve ark. 2002) sonuçlarından yüksek bulunmuş olup, Kim ve ark. (2011) yılında yapmış oldukları çalışmada AD'li köpeklerde çimlere karşı hiç vakanın pozitiflik vermediğini bildirmişlerdir. Öte yandan, sonuçlarımızın Nesbitt (1978) yılında yaptı̆̆ çalışmadan (\%76) düşük olduğu tespit edilmiştir. Zur ve ark.(2002) AD'li 266 köpekten 94'ünün en az 1 ila 9 farklı çim polenine karşı hassasiyet gösterdiğini, dişilerin erkeklere kıyasla istatiksel oranda daha fazla hassasiyet gösterdiklerini, benzer şekilde mevsimsel farkll11klarda sonbahar ve yaz aylarında köpekler arasındaki hassasiyetin arttığını tespit etmişlerdir. Bu araştırmada diğer araştırmalardan farklı olarak numuneler kış aylarında toplanmıştır. Buna rağmen diğer çalışmalara oranla çim polenine karşı pozitiflik oranı oldukça yüksek $(\% 47)$ bulunmuştur. Bu oranın yüksek olması iklim ve coğrafi konumla ve Samsun ilinin Orta Karadeniz Bölgesi'nde ve sürekli yağış alan ve doğal plantasyonun yüksek olduğu bir şehir olması ile açıklanabilir.

Zur ve ark. (2002) çime karşı pozitiflik bulunan köpekler arasında yaş veya cinsiyet farklillğının önemsiz olduğunu ortaya koymuşlardır. Bu noktada çalışmamızdaki köpeklerinde de çim karışımlarına karşı hassasiyetlerinde cinsiyet, $1 \mathrm{rk}$, beslenme, yaşa bağlı herhangi bir istatiksel farklılık görülmemiştir. Kültürü yapılan bitkiler içinde yer alan çavdar otu (Ryepollen), gibi diğer otları oluşturan çalışmamız test panelinde Parietaria (Wall pellitory), Ragweed (Ambrosia), Stinging netle, Lamb'squarter, English Plantain, Mugwort, Sorrel yer almaktadır. Yüzde 47 oranında en sık 5. olarak görülen, Lepidoglyphus, Ryepollen, Grass-Mix alerjenleri yer almıştır. Altıncı sırada \%38 oranında muz familyası bitki polenlerinden English Plantain ve kuzukulaği poleni olan Sorrel ve bunun yanında isırgan otu poleni olan Stinging nettle ile albüm otu poleni olan Lambs quarter \%19 görülme oranı ile 8. sırada yer aldığ1 tespit edilmiştir. Dokuzuncu sırada yer alan pelin otu poleni olan Mugwort \%14 oraninda AD'li köpeklerde görülmüştür. Saman nezlesi poleni Ragweed (Ambrosia) \%9,5 görülme oranı ile 10. sirada yer almıştır. Son olarak 11. sırada sadece birer köpekte görülen $\% 4,8$ oranı ile yapışkan otu poleni olan Parietaria (Wall pellitory) yer almaktadır.

Ot polenlerinin ayr1 ayrı hassasiyetlerinin araştırıldığ1 çalışmalar sayıca az olsa da birlikte değerlendirildikleri çalışmalarda köpeklerde \%17,1 (Masuda ve ark. 2000), \%25,5 (Kim ve ark. 2011), \%45,5 (Zur ve ark. 2002) oranlarında seropozitiflik tespit edilmiştir. Kang ve ark. (2014) yaptıkları çalıșmada ot polenlerinin hassasiyetlerinin diğer alerjenlere oranla önemsiz olduğunu belirtmiş olsalar da araştırıcılar English Plantain' $1 \% 52$ oranında mevcut çalışmamızdan (\%38) daha yüksek bulmuşlardır. Bununla beraber, AD'li köpeklerde Ragweed (Ambrosia) \%59 (Nesbitt ve ark. 1984) bir bașka çalıșmada da \%13,6 (Roussel ve ark. 2013) olarak bulunmuştur. Bu araştırmalardan elde edilen sonuçların, çalışmamızda elde edilen bulgulardan daha yüksek olduğu $(\% 9,5)$ görülmektedir. Pelin otu poleni olarak bilinen Mugwort ise mevcut çalışmamızda AD’li köpeklerde \%14 olarak görülmüştür. $\mathrm{Bu}$ oran sıras1 ile \%9,6 (Chanthick ve ark. 2008), \%10 (Sture ve ark. 1995) ve $\% 11,9$ (Roussel ve ark. 2013) bulunan çalışmalardan 
yüksek olmakla beraber $\% 52$ oranında bulan Nesbitt ve ark. (1984)'dan düşüktür. Öte yandan Zur ve ark. (2002) yapmış oldukları çalışma sonuçlarına göre ot polenlerinin AD'li köpeklerdeki en önemsiz alerjen grubunu oluşturduğunu ve çalışmalarındaki 266 köpekten 79'unun hassasiyet gösterdiğini ve bu köpeklerde cinsiyet ve yaşın önemsiz olduğunu ancak 1rk bazında Labrador Retriever'ların bu alerjenlere hassasiyet gösterme oranlarının istatiksel olarak yüksek bulunduğunu ortaya koymuşlardır. Aksine aynı araştırmacılar Daschund 1rk1 köpeklerde bahsi geçen alerjen grubuna hassasiyet oranlarının istatiksel olarak oldukça düşük olduğunu tespit etmişlerdir (Zur ve ark. 2002). Bizim çalışmamızda ise ot polenlerinden çavdar otunun (Rye pollen) dişında kalan ot polenlerin hassasiyet oranı diğer alerjenlere oranla daha önemsiz olarak tespit edilmiştir.

Çalışmamızda AD'li köpeklerde hassasiyet bakımından altınc1 sırada \%38 oranında insekt grubundan tek alerjen olan Ctenocephalides spp. yer almaktadır. Pire kaynaklı alerjiler, veteriner dermatoloji pire enfestasyon olgularının çok yaygın olarak rastlanilmasi nedeniyle serolojik ve IDT testlerine gereksinim duyulmadan klinik olarak teşhis edilebilirler.

İki yüz altmışaltı köpeğin dâhil edildiği ve alerjenlerin tespit edildiği KAD'li köpeklerden 102 tanesinin pire alerjenlerine pozitif reaksiyon verdiği, bu pozitifliğin de gerek yaş, 1 rk ve cinsiyetle ilgili bir farklılık oluşturmadığı tespit edilmiştir (Zur ve ark. 2002). Ancak bahsi geçen araştırmacilar pire alerjisine pozitiflik veren 75 köpeğin aynı zamanda da ev tozu akarlarına da pozitiflik verdiğini tespit etmişlerdir. Çalısmamızda pire alerjenine pozitiflik oranı $(\% 38)$ ise Zur ve ark. (2002) ile aynı oranda bulunurken ülkemizde gerçekleștirilen AD'li köpeklerde yapılan bir çalışmada (Temizel ve Aytug 2011) pire alerjenine pozitiflik oranına (\%48) göre düşük bulunmuştur. Bununla birlikte çalışmamız sonuçlarının aynı araştırmacıların sonuçlarında olduğu gibi pire alerjenine pozitiflik veren köpeklerin tamamının birinci tip ev tozu akarı ile de pozitiflik verdiği tespit edilmiştir. Kim ve ark. (2011)'nın pire alerjeni yönünden AD'li köpeklerde buldukları \%25,5 pozitiflik oranı çalışmamızdan düşük olmakla beraber Kang ve ark. (2014) yaptıkları çalışmalarında AD'li köpeklerin pire alerjeni bakımından daha da düşük $(\% 7,9)$ pozitiflik verdiğini ortaya koymuşlardır. Pire alerjileri ile ilgili çalışmaların tümünde AD’li köpeklerden yaş, 1 rk, cinsiyet veya mevsimsel faktörlerin etkili olmadığı sonucuna varılmış olsa da çalışmamızda AD'li dişi köpeklerin pire alerjenine pozitiflik verme oran $(\% 87,5)$ ile erkek köpeklerin pire alerjenine pozitiflik verme oranı $(\% 38,1)$ arasında istatiksel farkll11k $(\mathrm{p}<0.05)$ bulunmuştur.

\section{SONUÇ}

Mevcut çalışma ile ilk kez Samsun ili ve çevresinden Ondokuz Mayis Üniversitesi Veteriner Fakültesi Eğitim ve Araştırma Hastanesine getirilen değişik ırk, cinsiyet ve yaşlardaki 21 adet AD'li köpekte 20 farklı alerjene özgü serum spesifik $\operatorname{IgE}$ düzeylerine bakılmıştır. Bu araştırma ile ev tozu akarlarının sadece insan sağlığı açısından değil, evlerde bakıp beslenen köpeklerin sağllğı açısından da önemli olduğu anlaşılmıştır. Bu nedenle Samsun yöresinde, evlerinde köpek besleyen kişilerin ev tozu akarları açısından temizlik ve hijyen kurallarına dikkat etmeleri gerekmektedir. Araştırmamızda hasta sahiplerinden beslenme şekillerinde kuru mama bulunan köpeklerin çoğunda aynı marka köpek kuru maması kullanıldığ1 bilgisine ulaşılmıştır. Bu nedenle köpek kuru maması imalatı sirasinda kullanilan ham maddelerin depo akarları yönünden mutlaka incelenmesi ve mümkün olduğunca depo akar1 yönünden arî hammaddelerin kullanılması gerekmektedir.

Bununla birlikte Samsun yöresinde AD'li köpeklerde antijenlere spesifik serum $\mathrm{IgE}$ oranlarının yüksek oranda seropozitiflik vermesinden dolayı evlerde bakılan kedilerinde serum spesifik IgE antijen profillerinin incelenmesi gerektiği düşünülmektedir.

\section{TEŞEKKÜR}

Bu çalssma, Ondokuz Mayıs Üniversitesi Bilimsel Araştırma Projeleri Koordinasyon Birimince PYO.VET.1904.17.016 proje numarast ile desteklenmişve Öykü Barll'nn ayn isimli Yüksek Lisans Tezi'nden özetlenmistir. Ayrnca çalssmann istatistiğini yapan Saym Prof.Dr. Filiz. Akdağ'a s̈̈̈kranlarmį sunari:

Calısma Ondokuz Mayıs Üniversitesi, Hayvan Deneyleri Yerel Etike Kurulunca (Etik Kurul No:2016/63) onaylanmıştır.

\section{KAYNAKLAR}

Açıcı M, İğde M, Beyhan YE, Pekmezci GZ, Gürler AT, Hökelek M, Umur Ş. Ev ve işyerlerinde ev tozu ve akar faunası. Ondokuz Mayıs Üniv Tip Fak Derg. 2009; 25(1):

Carlotti DN, Costargent F. Analysis of positive skin tests in 449 dogs with allergic dermatitis. Prakt Med Chir An de Cie. 1992; 27: 53-69.

Chanthick C, Anaman S, Buathet K. The prevalence of positive intradermal allergy tests in 114 dogs with atopic dermatitis in the Bangkok metropolis, Thailand. Vet Immunol Immunopathol. 2008; 126: 256-262.

Codner EC, Tinker MK. Reactivity to intradermal injections of extracts of house dust and house dustmite in healthy dogs and dogs suspected of being atopic. J Am Vet Med Assoc. 1995; 206: 812-816.

De Weck AL.What can we learn from the allergic zoo? Int Arch Allergy Immunol. 1995; 107: 13-18. 
Favrot C, Steffan J, Seewald W, Picco F. A prospective study on the clinical features of chronic canine atopic dermatitis and its diagnosis. Vet Dermatol. 2010; 21(1): 23-31.

Griffin CE, DeBoer DJ. The ACVD task force on canine atopic dermatitis (XIV): clinical manifestations of canine atopic dermatitis. Vet Immunol Immunopathol. 2001; 81(3-4): 255-269.

Halliwell RE, Schwartzman RM, Rockey JH. Antigenic relationship between human $\operatorname{IgE}$ and canine $\mathrm{IgE}$. Clin Exp Immunol. 1972; 10(3): 399-407.

Hammerling R, De Weck AL. Comparison of two diagnostic tests for canine atopy using monoclonal anti-IgE antibodies. Vet Dermatol. 1998; 9: 191-199.

Hill PB, DeBoer DJ. The ACVD task force on canine atopic dermatitis (IV): environmental allergens. Vet Immunol Immunopathol. 2001; 81: 169-186.

Jeffers JG, Shanley KJ, Meyer EK. Diagnostic testing of dogs for food hypersensitivity. J Am Vet Med Assoc. 1991; 198(2): 245-250.

Kang MH, Kim HJ, Jang HJ, Park HM. Sensitization rates of causative allergens for $\operatorname{dogs}$ with atopic dermatitis: detection of canine allergen-specific IgE. J Vet Sci. 2014; 15: 545-550.

Kim HJ, Kang MH, Park HM.Common allergens of atopic dermatitis in dogs: comparative finings based on intradermal tests. J Vet Sci. 2011; 12: 287-290.

Masuda K, Sakaguchi M, Fujiwara S, Kurata K, Yamashita K, Odagiri T, Nakao Y, Matsuki N, Ono K, Watari T, Hasegawa A, Tsujimoto $\mathbf{H}$. Positive reactions tocommon allergens in 42 atopic dogs in Japan. Vet ImmunolImmunopathol. 2000; 73: 193-204.

Mueller RS, Bettenay SV, Tideman L. Aero-allergens in canine atopic dermatitis in southeastern Australia based on 1000 intradermal skin tests. Aust Vet J. 2000; 78: 392-399.

Nesbitt GH. Canine allergic inhalant dermatitis: a review of 230 cases. J Am Vet Med Assoc. 1978; 172: 55-60.

Nesbitt GH, Kedan GS, Cacciolo P. Canine atopy. Ethiology and diagnosis. Comp Cont Educ Pract. 1984; 6: 73-85.

Nødtvetd A, Bergvall K, Sallander M, Egenvall A, Emanuelson U, Hedhammar A.A case-control study of risk factors for canine atopic dermatitis among boxer, bullterrier and West Highland white terrier dogs in Sweden. Vet Dermatol. 2007; 18: 309-315.

Prelaud P, Guague ÁE, Alhaidari Z, Faivre N, Heripret D. Reevaluation of diagnostic criteria of canine atopic dermatitis. Rev Med Vet. 1998; 149: 1057-1064.

Rosser Jr EJ. Diagnosis of food allergy in dogs. J Am Vet Med Assoc. 1993; 203(2): 259-262.

Roussel AJ, Bruet V, Bourdeau PJ. Characterisation of dog sensitisation to grass pollen in western France from 1999 to 2010. Vet Rec. 2013; 172: 686.

Saridomichelakis MN, Koutinas AF, Gioulekas D, Leontidis L. Canine atopic dermatitis in Greece:clinical observations and the prevalence of positive intradermal test reactions in 91 spontaneous cases. Vet Immunol Immunopathol. 1999;69: 61-73.

Scott DW. Observations on canine atopy. J Am Anim Hosp Assoc. 1981; 17: 91-100.

Scott DW, Miller WH, Griffin CE. Muller and Kirk's Small Animal Dermatology $5^{\text {th }}$ edn. Philadelphia: W.B. Saunders, 1995; pp. 500-518.
Sousa CA, Norton AL. Advances in methodology for diagnosis of allergic skin disease. Vet Clin Small Anim Pract.1990; 20(6): 1419-1427.

Sture GH, Halliwell RE, Thoday KL, van den Broek AH, Henfrey JI, Lloyd DH, Mason IS, Ferguson E. Canine atopic disease: the prevalence of positive intradermal skin tests at two sites in the north and south of Great Britain. Vet Immunol Immunopathol. 1995; 44: 293-308.

Temizel EM, Aytug N. Intradermal testing results and clinical features in dogs with atopic dermatitis in Turkey. J Biol Environ Sci. 2011; 5: 87-89.

Willemse $T$, van den Brom WE. Investigation of the symptomatology and the significance of immediate skin test reactivity in canine atopic dermatitis. Res Vet Sci. 1983; 34: 261-265.

Willemse T, van den Brom WE, Rijnberk A. Effect of hyposensitization on atopic dermatitis in dogs. J Am Vet Med Assoc. 1984; 184: 1277-1280.

Zunic M. Comparison between immunodot tests and the intradermal skin test in atopic dogs. Vet Dermatol. 1998; 9: 201-205.

Zur G, Ihrke PJ, White SD, Kass PH. Canine atopic dermatitis: a retrospective study of 266 cases examined at the University of California, Davis, 1992-1998. Part I. Clinical features and allergy testing results. Vet Dermatol. 2002; 13(2):89-102. 